\title{
STRUKTUR KOMUNITAS FORAMINIFERA BENTHIK BERDASARKAN HABITAT DI PERAIRAN SULAWESI UTARA
}

\author{
(The Community Structure of Benthic Foraminifera Base on Their Habitat at North \\ Sulawesi Waters)
}

\author{
Jeine F. Bawole ${ }^{1 *}$, Janny D. Kusen ${ }^{1}$, Joice R.T.S.L.Rimper ${ }^{1}$
}
1. Program Studi Ilmu Kelautan Fakultas Perikanan dan Ilmu Kelautan Universitas Sam Ratulangi, Manado.
*e-mail : florenciajeine@gmail.com

Research about community structure of foraminifera has been done at several sites in North Sulawesi waters within aims were to knew the foraminifera benthic species and their community structure such as density, diversity, evenness and domination. Also to knew the distribution pattern generally. .Foraminifera sample was collected in the coastal line intertidal zone, in several depths, and in the different ecosystem such as mangrove, seagrass, and coral reefs as well. The sample was taken volumetrically at Salurang Village (Station 1), Binebas Village (Station 2), Bulo Village (Station 3), Malalayang Village (Station 4), and Molas Village (Station 5). The coordinate position of each site had been noted according to the GPS results performance. The foraminifera sample that mixed together with sand and clay was collected by small collector tools and then put in the labeled $240 \mathrm{ml}$ volume plastic container. Afterward, the sample has been moved and identified, and data analysis gathered at the Marine Biology Laboratory of Faculty of Fisheries and Marine Science. The results had been showed that all substrates at each study site consist of sand clay. As many as 10 species of foraminiferawere identified from all study sites within total foraminifera number were 1185 individuals. The highest individuals density had been found at Station 4 that was Bacullogypsina sphaerulata.The distribution pattern of each species within each study site mostly as the uniform pattern that following by contagious pattern. Only one study site had been shown the random pattern. Uniform or evenness distribution pattern was commonly found in the nature realm.

\begin{abstract}
Keywords : foraminifera, community, density, distribution
Penelitian mengenai struktur komunitas foraminifera telah dilakukan di beberapa lokasi di perairan Sulawesi Utara yang bertujuan untuk mengetahui jenis-jenis foraminifera benthik dan struktur komunitas berupa kepadatan, keanekaragaman, kemerataan dan dominansi. Juga untuk mengetahui pola penyebaran foraminifera secara umum. Pegambilan sampel foraminifera dilakukan di garis pantai di zona intertidal, di beberapa kedalaman, dan juga di ekosistim yang berbeda seperti mangrove, lamun dan terumbu karang. Sampel diambil secara volumetri di Desa Salurang (Stasiun 1), Desa Binebas (Stasiun 2), Desa Bulo (Stasiun 3), Kelurahan Malalayang (Stasiun 4, dan Kelurahan Molas (Stasiun 5). Koordinat dari masingmasing stasiun dicatat mengacu pada tampilan posisi koordinat pada alat GPS (Global Positioning System). Pada setiap titik di tiap stasiun sampel yang terdapat dalam sedimen pasir dan lumpur diambil menggunakan alat keruk sekop dan dimasukkan dalam wadah plastik berlabel ukuran $240 \mathrm{ml}$. Sampel selanjutnya dibawa ke Laboratorium Biologi Kelautan Fakultas Perikanan dan IImu Kelautan untuk proses identifikasi, pengambilan dan analisis data. Hasil penelitian menunjukkan bahwa semua substrat pada masing-masing stasiun penelitian terdiri dari pasir bercampur lumpur. Teridentifikasi ada sebanyak 10 spesies foraminifera pada semua stasiun penelitian dengan total individu sebanyak 1185 individu foraminifera. Struktur komunitas menunjukkan bahwa kepadatan individu tertinggi terdapat di Stasiun 4 yaitu pada spesies Baculogypsina sphaerulata. Pola penyebaran foraminifera per jenis per stasiun pada umumnya seragam, diikuti penyebaran mengelompok. Hanya ada satu jenis di satu titik pengamatan yang menunjukkan pola penyebaran acak. Penyebaran secara seragam atau merata merupakan pola penyebaran yang umumnya terjadi di alam.
\end{abstract}

Kata Kunci : foraminifera, komunitas, kepadatan, distribusi 


\section{PENDAHULUAN}

Foraminifera merupakan organisme bercangkang yang banyak melimpah di berbagai lingkungan laut. Dalam $1 \mathrm{~cm}^{3}$ sedimen bisa terdapat ratusan individu hidup, bersama dengan banyak cangkang mati (Levinton, 2009). Foraminifera merupakan salah satu organisme yang mayoritas anggotanya hidup di lingkungan laut, dengan ukuran tubuh kurang lebih $0.1-2 \mathrm{~mm}$. Berdasarkan cara hidupnya foraminifera dibagi 2 yaitu : Foraminifera planktonik dan benthik (Brasier, 1980). Foraminifera benthik memiliki habitat pada dasar laut dengan cara hidup secara 'vagile' (merambat / merayap) dan 'sessile'" (menambat). Alat yang digunakan untuk merayap pada benthos yang 'vagile' ialah 'pseudopodia (Anugrah, 2012). Sampai sekarang pendalaman studi khusus biota foraminifera di perairan Sulawesi Utara pada umumnya belum banyak. Di sisi lain pengetahuan tentang keanekaragaman hayati foraminifera sangat penting karena diperlukan dalam bidang studi biostratigrafi, paleoekologi dan paleobiogeografi.

\section{METODE PENELITIAN}

Pelaksanaan penelitian di lapangan selama 3 (tiga) bulan didahului dengan penelitian awal (Preliminary Research). Pengambilan sampel berlokasi di Kabupaten Kepulauan Sangihe yaitu di perairan Desa Salurang pada koordinat $3^{\circ} 28^{\prime} 38^{\prime \prime}$ LU dan 125'39'57" BT, Desa Binebas pada koordinat $3^{\circ} 28^{\prime} 38^{\prime \prime}$ LU dan 12539'55" BTdan Desa Bulo pada koordinat 3o30'48" LU dan 125'38'30" BT serta di Perairan Kota Manado (Lampiran 1) yaitu di perairan Pantai Malalayang pada koordinat $1^{\circ} 27^{\prime} 37,08^{\prime \prime}$ LU dan 124.47'03" BT dan perairan Pantai Molas pada koordinat 1'32'09" LU dan 124\%49'55" BT.

Pengambilan sampel sedimen dilakukan dengan metode volumetri, (Brasier, 1980). Sampel diambil pada saat perairan sedang surut. Sampel sedimen kemudian dicuci dengan air bersih dan dikeringkan di bawah sinar matahari sampai benar-benar kering. Setelah kering sampel foraminifera disortir (dipilah atau dipisahkan) dari lumpur dan butiran pasir kemudian ditimbang. Karena banyaknya sampel individu foraminifera yang didapatkan setelah penimbangan makahanya sekitar $10 \%$ dariberat total foraminifera yang diambil untuk dianalisis yang mengacu pada Brasier (1980) untuk analisis volumetri. Kemudian sampel diidentifikasi secara mikroskopis menggunakan mikroskop stereo.

$$
\text { Setelah sampel selesai }
$$

diidentifikasi selanjutnya dilakukan analisis data dengan cara menghitung indeks-indeks dalam struktur komunitas foraminifera serta analisis Pola Penyebaran. Indeks-indeks tersebut yaitu:

\section{Indeks Kepadatan}

Untuk mengetahui kepadatan individu digunakan analisis menurut Cedhagen (1997) denaan rumus :

Total individu seluruh spesies

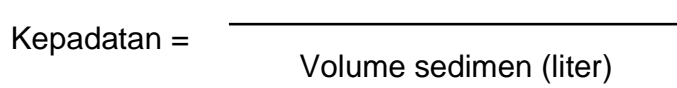

Untuk mengetahui kepadatan relatif digunakan analisis menurut Cox (1967) dengan rumıs .

Jumlah individu setiap spesies

Kepadatan relatif $(\%)=$

Jumlah individu seluruh spesies

\section{Indeks Keanekaragaman}

Untuk menganalisis keanekaragaman spesies digunakan indeks keanekaragaman menurut Ludwig and Reynolds (1988) :

$$
H^{\prime}=-\Sigma \quad \ln \frac{\mathrm{ni}}{\mathrm{N}}
$$

Keterangan :

$H^{\prime}=$ Indeks keanekaragaman spesies 
ni = Jumlah individu dalam spesies ke-I

$\mathrm{N}$ = Jumlah individu total

Berdasarkan formula di atas, indeks keanekaragaman Ludwig and Reynolds (1988) dikategorikan sebagai berikut :

$H$ '>1:Keanekaragaman populasi kecil/ tidak stabil

$H^{\prime}=1$ : Keanekaragaman populasi sedang

$H^{\prime}<1$ :Keanekaragaman populasi tinggi/ stabil

\section{Indeks Kemerataan atau Keseragaman (Ludwig and Reynolds, 1988)}

Kemerataan atau Keseragaman yang diwujudkan dalam indeks regularitas (equitability evenness index) adalah suatu penggambaran mengenai sebaran individu setiap spesies dalam komunitas. Indeks keseragaman (E) dihitung berdasarkan persamaan berikut :

$$
E=\frac{H^{\prime}}{\ln (S)}
$$

Keterangan :

$$
\begin{aligned}
& \mathrm{E} \quad=\quad \text { Keseragaman atau } \\
& \text { Kemerataan } \\
& \mathrm{H}^{\prime} \quad=\text { Indeks keragaman spesies } \\
& \mathrm{Ln} \quad=\text { Logaritma natural } \\
& \mathrm{S} \quad=\text { Jumlah spesies }
\end{aligned}
$$$$
\text { Nilai Indeks Keragaman ( } \left.\mathrm{H}^{\prime}\right)
$$
berkisar antara $0_{-}$, kategori keragaman biota menurut Shannon dan Wiener adalah sebagai berikut:

$\mathrm{H}^{\prime}<1$ = Keragaman Kecil

$H^{\prime}=1=$ KeragamanSedang

$H^{\prime} \geq 1=$ KeragamanTinggi

\section{IndeksDominasi}

Indeks Dominansi (Ludwig and Reynolds, 1988)

$$
D=\sum(n i / N)
$$

Ket. :

$\mathrm{D}=$ Indeks dominansi $\mathrm{ni}=$ Jumlah individu dalam spesies ke-I

$\mathrm{N}=$ Jumlah individu total

Kriteria Indeks Dominasi adalah sebagai berikut:

$0<\mathrm{C} \leq 0,5=$ Dominansi rendah

$0,5<\mathrm{C} \leq 0,75=$ Dominansi sedang

$0,75<\mathrm{C} \leq 1=$ Dominansi tinggi

\section{Pola Penyebaran}

Pada pola

penyebaran menggunakan indeks dispersi morisita menurut Krebs, 1989. Indeks ini dapat dihitung dengan persamaan sebagai berikut :

$$
\mathrm{Id}=\mathrm{n}\left(\Sigma \mathrm{X}^{2}-\Sigma \mathrm{X} /\left(\sum \mathrm{X}^{2}-\Sigma \mathrm{X}\right)\right.
$$

Keterangan :

Id = Indeks dispersi Morisita

$\mathrm{n}=$ Ukuran contoh (jumlah kuadrat)

$\Sigma x=$ Total dari jumlah individu suatu oganisme dalam kuadrat

$\Sigma x^{2}=$ Total dari kuadrat jumlah individu suatu organisme dalam kuadrat, jika :

Kriteria :

ID $<1$, Pola penyebaran teratur atau seragam

ID $=1$, Pola penyebaran acak

ID > 1, Pola penyebaran mengelompok

\section{HASIL DAN PEMBAHASAN}

\section{Komposisi Spesies}

Jumlah spesies yang ditemukan di beberapa perairan Sulawesi Utara seluruhnya berjumlah 10 spesies yang terdiri dari 2 famili. Adapun 2 famili itu adalah Calcarinidae (Baculogypsina sphaerulata, Baculogypsina sphaerica, Calcarina gaudicaudii, Calcarina hispida, Calcarina defrancii, Calcarina spengleri, Calcarina mayori, Calcarina sp) dan famili Nonionidae (Elpidium crispum). 


\section{Substrat}

Stasiun 1 (Desa Salurang) substrat berpasir, Stasiun 2 (Desa Binebas) substrat berlumpur, Stasiun 3 (Desa Bulo) substrat berpasir, sedangkan pada perairan Kota Manado sebagai Stasiun 4 (Kelurahan Malalayang) memiliki substrat berpasir dan pada Stasiun 5 (Kelurahan Molas) substrat berlumpur dan berpasir.

Kepadatan

Kepadatan individu dengan nilai tertinggi terdapat pada Stasiun 4 (Kel. Malalayang) dengan nilai kepadatan 55.6 (56 ind./liter) pada spesies $B$. sphaerulata sedangkan nilai kepadatan terendah terdapat di Stasiun 1 (Desa Binebas) dengan nilai kepadatan 0.38 ind./liter pada spesies $C$. mayori. Nilai kepadatan relatif tertinggi terdapat pada Stasiun 3 (Desa Bulo) dengan nilai $66.67 \%$ pada spesies $B$. sphaerulata dan untuk kepadatan relatif terendah terdapat pada Stasiun 1 (Desa Binebas) dengan nilai $0.38 \%$ pada spesies E. crispum.

Keanekaragaman (H'), Kemerataan (E) dan Dominansi (C)

Nilai keanekaragaman tertinggi terdapat pada Stasiun 5 (Kelurahan Molas) di ekosistem mangrove dengan nilai keanekaragaman $\left(H^{\prime}\right)=1.748\left(H^{\prime}=>1\right)$ dan nilai keanekaragaman yang terendah terdapat pada Stasiun 3 (Desa Bulo) dengan nilai $H^{\prime}=1.092$. Sedangkan untuk nilai kemerataan (E) tertinggi terdapat pada Stasiun 3 (Desa Bulo)

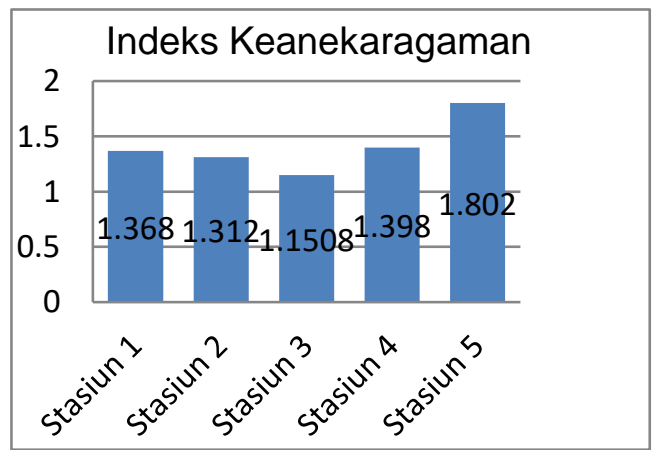

Gambar 1. Indeks keanekaragaman pada 5 stasiun pengamatan

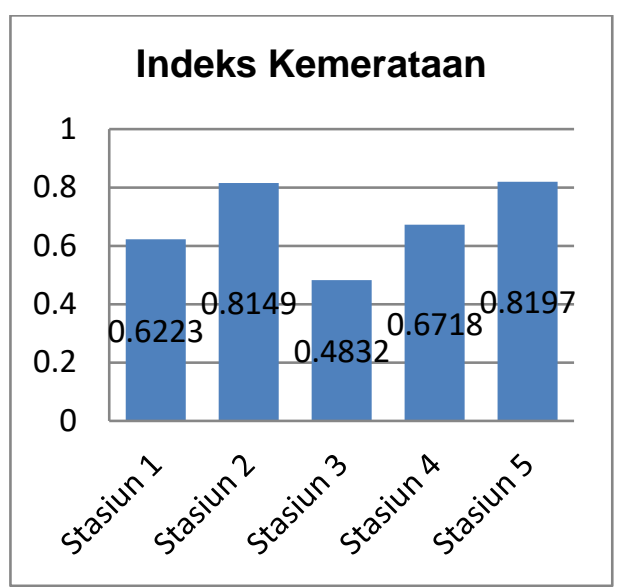

Gambar 2. Indeks kemerataan pada 5 stasiun pengamatan

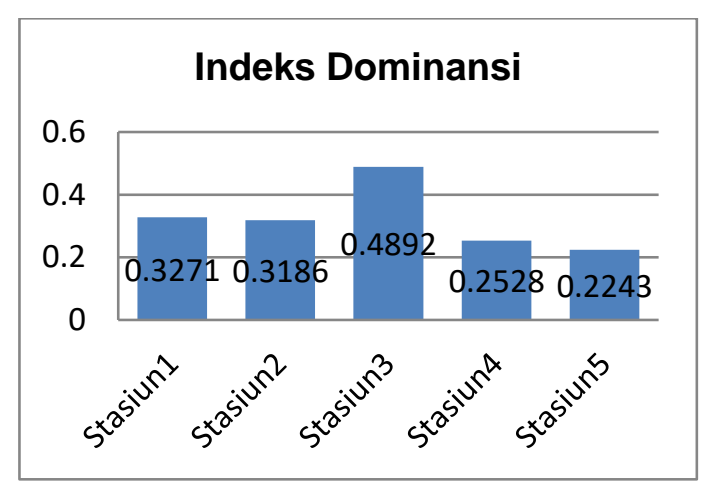

Gambar 3. Indeks dominansi pada 5 stasiun pengamatan

dengan nilai 0.840 dan nilai kemerataan terendah pada Stasiun 5 (Kelurahan Molas) di ekosistem mangrove dengan nilai 0.561 . Untuk nilai dominansi $(C)$ tertinggi terdapat pada Stasiun 5 (Kelurahan Molas) pada ekosistem mangrove dengan nilai 0.480 dan nilai dominansi terendah terdapat pada Stasiun 3 (Desa Bulo) dengan nilai 0.208.

\section{Pola Penyebaran}

Berdasarkan analisis pola penyebaran diperoleh pola penyebaran mengelompok, seragam dan acak. Penelitian tentang keberadaan foraminifera di dua lokasi di perairan Sulawesi Utara yaitu di Kecamatan Tabukan Selatan Tengah Kabupaten Kepulauan Sangihe sebanyak 10 spesies foraminifera dan Kota Manado 9 spesies foraminifera. Padahal 
Watupongoh (1999) menemukan sekitar 32 spesies hanya di perairan Kota Manado. Khususnya di peraian Malalayang ada 32 spesies dibandingkan dalam penelitian ini hanya 8 spesies di perairan Malalayang. Secara khusus titik sampel yang didapatkan tidak tepat sama akan tetapi secara umum ada gambaran perubahan kondisi lingkungan perairan selang hampir 20 tahun. Tomascik et al. (1997) dalam Watupongoh (1999) mengemukakan bahwa di Teluk jakarta ditemukan ada 66 spesies foraminifera di habitat pecahan koral dan lumpur, di Sorong dalam habitat pasir ditemukan 35 spesies. Begitu juga di perairan Pulau Batam di Teluk Kering ada 37 spesies ditemukan dalam habitat pasir.

Foraminifera benthik sebagai organisme bersel tunggal (sama dengan foraminifera planktonik) yang terbungkus dengan cangkang (test) mempunyai kemampuan untuk dapat menempati berbagai wilayah laut mulai dari zona supertidal di atas litoral sampai pada kedalaman terdalam di zona hadal abbysal, menurut Boltovskoy and Wright (1976). Menunjukkan bahwa organisme yang masuk kelompok protista ini mempunyai kemampuan beradaptasi yang tinggi. Sekalipun perlu ada kajian lebih mendalam dari perubahan jumlah spesies yang cenderung berkurang di perairan Malalayang dapat mengindikasikan adanya perubahan kualitas habitat bagi foraminifera.

Substrat yang ada menunjukkan karakteristik substrat di perairan pesisir yang diketahui juga terdapat sumber makanan dari organisme bersel tunggal ini. Lumpur yang bercampur pasir merupakan campuran antara butiran padat kecil dengan material organik yang lagi terurai sebagai sumber nutrisi foraminifera. Sekalipun ukuran butiran padat yang relatif sama dengan ukuran tubuh foraminifera umumnya ditemukan sebagai sedimen di dasar perairan. Dalam lingkungan laut perairan tropis dangkal keberadaan foraminifera memberikan kontribusi yang cukup signifikan sebanding dari sedimen karbonat (Muray 1991 dalam Reymond et al. 2012).

Sekalipun adanya penurunan jumlah spesies di Perairan Malalayang (Stasiun 4) akan tetapi nilai kepadatan individu tertinggi (56 ind./liter) terdapat di perairan ini dibandingkan dengan stasiun penelitian lainnnya yang ditunjukkan oleh spesies B. sphaerulata. Perairan Malalayang merupakan perairan terbuka yang menghadap Teluk Manado yang pada kondisi terkini merupakan kawasan perairan yang banyak dikunjungi manusia (anthropognik). Dinamika pergerakan massa air di pantai Malalayang relatif lebih tinggi jika dibandingkan dengan Stasiun 1 di Desa Binebas yang relatif tenang dan terlindung. Tingginya pergerakan massa air yang menerpa garis pantai memungkinkan terjadinya percampuran antara sedimen yang juga terdapat organisme foraminifera dengan permukaan lapisan air memungkinkan tingginya intensitas masuknya oksigen dibandingkan dengan perairan tenang seperti di Stasiun 1 dimana kepadatan individu paling rendah dari semua staiun penelitian.

Didapatkan nilai keanekaragaman $\left(\mathrm{H}^{\prime}\right)$ foraminifera tertinggi ada di Stasiun 5 (Kelurahan Molas) di ekosistem mangrove dengan nilai keanekaragaman $\left(\mathrm{H}^{\prime}\right)=1.748\left(\mathrm{H}^{\prime}=>\right.$ 1). Nilai keanekaragaman yang $>1$ menunjukkan bahwa kondisi lingkungan disitu stabil. Hal ini sangat dimungkinkan karena, selain kawasan pantai Molas merupakan perairan terbuka yang sama dengan peraian Malalayang, akan tetapi di kawasan ini masih ditemukan ekosistem mangrove yang tidak ada di perairan Malalayang. Adanya serasah mangrove yang terurai di perairan akan bercampur sedimen, sehingga kondisi nutrisi tempat hidup foraminifera sangat melimpah dengan bahan organik. Kondisi ini sangat memugkinkan bagi berbagai jenis atau spesies foraminifera 
mendapat peluang untuk menempati ruang ini. Sehingga dari parameter ketersediaan bahan organik maka Stasiun ini paling tinggi bersamaan dengan dinamika percampuran masa air yang tinggi dibandingkan dengan stasiun laiinya.

Nilai kemerataan $(E)$ tertinggi yang mencapai $>0,5$ terdapat pada Stasiun 3 (Desa Bulo) dengan nilai 0.840. Hal ini menunjukkan bahwa adanya kemerataan dari keberadaan spesies pada masing-masing stasiun penelitian. Di sisi lain Odum (1996) menyatakan bahwa dalam situasi meratanya sebaran organisme dalam suatu ekosistem menunjukkan bahwa ekosistim tersebut cenderung dalam kondisi ekosistim yang stabil. Hal ini memang ditunjang juga oleh profil morfologi tubuh organisme foraminifera yang mempunyai kemampuan bisa berada di berbagai ekosistem.

Nilai dominansi (C) dalam suatu struktur komunitas biasanya berbanding terbalik dengan keanekaragaman. Bila sruktur komunitas menunjukkn beranekaragam dengan nilai $H^{\prime}>1$ maka biasanya mengindikasikan tidak ada spesies yang mendominasi. Kondisi ini terlihat pada nilai dominansi (C) yang diperoleh tertinggi ada di Stasiun 5 (Kelurahan Molas) pada foraminifera yang berada pada ekosistem mangrove dengan nilai antara 0,208 - 0.480. Nilai dominansi yang < 0,5 oleh Odum (1996) menunjukkan nilai dominasi yang kecil, atau tidak ada spesies yang mendominasi. Rendahnya nilai dominansi $(<0,5)$ menunjukkan bahwa foraminifera mempunyai keanekaragamn dan nilai kemerataan yang berbanding terbalik yaitu tinggi.

Penyebaran atau distribusi individu dalam suatu komunitas bermacam-macam, pada umumnya memperlihatkan tiga pola penyebaran, yaitu mengelompok, seragam, dan acak (Surasana, 1990). Melalui pendekatan distribusi Morisita yang dimodifikasi Krebs (1989) diperoleh 7 spesies $(70 \%)$ pola distribusi mengelompok, 10 spesies (100\%) pola distribusi seragam (teratur), 1 spesies $(10 \%)$ pola distribusi acak. Dengan demikian didapatkan gambaran umum pola distribusi foraminifera di stasiun penelitian cenderung pola distribusinya seragam.

\section{KESIMPULAN}

1. Foraminifera di beberapa perairan di Sulawsi Utara bersubstrat pasir bercampur lumpur teridentifikasi sebanyak 10 spesies pada 2 famili yaitu famili Calcarinidae spesiesspesies Baculogypsinasphaerulata, Baculog-ypsina sphaerica, Calcarina gaudicaudii, Calcarina hispida, Calcarina defrancii, Calcarina spengleri, Calcarina mayori, Calcarina $s p$, dan famili Nonionidae hanya ada species Elpidium crispum;

2. Kepadatan individu tertinggi di perairan Kelurahan Malalayang pada spesies Baculogypsina sphaerulata, yang terendah di perairan Desa Binebas pada spesies C. mayori. Kepadatan relatif di perairan Desa Bulo pada spesies $B$. sphaerulata, dan kepadatan relatif terendah di Desa Binebas pada species E. crispum. Keanekaragaman $\left(\mathrm{H}^{\prime}\right)$ tertinggi di perairan Kelurahan Molas pada ekosistem mangrove dengan nilai $\mathrm{H}^{\prime}>1$ artinya lingkungan forminifera yang stabil. Kemerataan foraminifera pada Desa Bulo dengan nilai mendekati 1 artinya populasi menunjukkan kemerataan atau keseragaman, sehingga dapat dikatakan bahwa jumlah individu setiap spesies sama atau tidak jauh berbeda; Nilai dominasi (D) tertinggi ada di Kelurahan Molas tapi masih dalam kisaran nilai mendekati 0 , berarti hampir tidak ada individu yang mendominasi, sejalan dengan tingginya nilai keanekaragaman;

3. Pola penyebaran foraminifera di lokasi studi pada beberapa perairan 
di Sulawesi Utara menunjukkan pola penyebaran yang seragam.

\section{DAFTAR PUSTAKA}

Anugrah, P.Y. 2012. Foraminifera. Teknik Geologi. Universitas Trisakti. Jakarta.

Brasier, M. D. 1980. Morphology and Habitat of Living Benthonic Foraminiferids from Caribear Carbonate Environments. Revista Espanola de Micropaleontologia VII (3). Hal : 567-568.

Chedagen, T. 1997. M.Sc Programenin Marine Science. University of Aarhus.

Cox, G. W. 1967. Laboratory Manual of General Ecology. Wm. C. Brown Company Publisher. USA. 165 hal.

Krebs, C.J. 1989. Ecological Methodology. Harper Collins Publisher, Inc. New York.

Levinton, J.S. 2009 Marine Biology. Function, Biodiversity, Ecology. 3rd Edition. Stony Book Univ. Oxford Univ. Press. 588 p.

Ludwig, J. A., Reynolds. J.F. 1988. Statistical Ecologycal ; A. Primer on Method Computing. A. Eiley. Interscience Publications. John Wiley and Sons, Inc. Canada. 337hal.

Odum, E. P. 1971. Fundamentals of ecology. 3rd ed. W.B. Saunders. Philadelphia. 574 hal.

Reymond, C.E, Uthicke, S., Pandolfi, J.M. 2012. Tropical Foraminifera as indicators of water quality and temperature.Proc. of the 12th International Coral Reef Symposium, Cairns, Australia
Surasana, S 1990. Pengantar Ekologi Tumbuhan. FMIPA Biologi ITB. Bandung

Watupongoh, N. N. J. 1999. Distribusi dan Kepadatan serta Keanekaragaman Foraminifera Benthik di Teluk Manado. Skripsi Fakultas Perikanan dan IImu Kelautan UNSRAT. Manado. 